\title{
Treatment guidelines for acquired hemophilia A
}

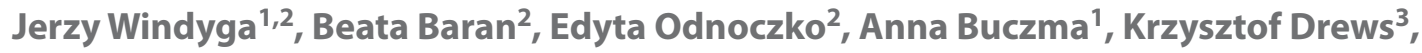 \\ Piotr Laudanski ${ }^{4}$, Bronislawa Pietrzak ${ }^{4}$, Piotr Sieroszewski ${ }^{5}$ \\ ${ }^{1}$ Department of Hemostasis Disorders and Internal Medicine, Institute of Hematology and Transfusion Medicine, Warsaw, Poland \\ ${ }^{2}$ Laboratory of Hemostasis and Metabolic Diseases, Institute of Hematology and Transfusion Medicine, Warsaw, Poland \\ ${ }^{3}$ Department of Perinatology and Women's Diseases, Poznan University of Medical Sciences, Poland \\ ${ }^{4} 1^{\text {st }}$ Chair and Department of Obstetrics and Gynecology, Medical University of Warsaw, Poland \\ ${ }^{5}$ Fetal Medicine and Gynecology Department Medical University of Lodz, Poland
}

\section{INTRODUCTION}

Obstetric and gynecological hemorrhage remains a frequent and severe complication that affects women at childbearing age and at the period of their full physical and professional activity. This problem applies to women in both developing and industrial countries. In the latter ones, including Poland, it is a result of constantly increasing rate of caesarean deliveries, accompanied by a several times higher risk of peripartum hemorrhage. For the experts from the World Health Organization there is a target to limit the global maternal mortality ratio from 216 per 100000 live births in 2015 to 70 per 100000 live births in 2030 (World Health Statistics 2018. Indicator 3.1.1). Decrease in the incidence of severe hemorrhages and their consequences can be achieved through providing medical care by the health care professionals who have knowledge about the causes, pathomechanism and pharmacotherapy of these complications. It is known, that the development, implementation and compliance with management algorithms for severe hemorrhages contributes to a significant reduction in the number of organ complications and mortality. According to the knowledge of the authors of this paper, acquired hemophilia $A$ is considered relatively rare as a cause of severe hemorrhage in gynecology and obstetrics.

Acquired hemophilia $\mathrm{A}(\mathrm{AHA})$ is an autoimmune disease caused by autoantibodies that impair the function of coagulation factor VIII (FVIII) and lead to a decrease in plasma FVIII activity. These antibodies are referred to as the circulating FVIII anticoagulant or FVIII inhibitor. Unlike congenital hemophilia $A$, with underlying mutation in the F8 gene located on the sex chromosome $X$, affecting males, acquired hemophilia $A$ occurs in both men and women. Decrease in FVIII activity in the course of AHA results in a tendency to excessive bleeding.
Although acquired hemophilia $A$ is classified as a severe bleeding disorder, in about $20-30 \%$ of cases it is initially manifested by only a minor bleeding, which often can even escape the attention of the physician [1]. However, it should be clearly stated, that as long as an FVIII inhibitor is detected in the patient's blood, the patient is at risk of experiencing a severe, potentially life-threatening hemorrhage.

Modern medicine has the effective tools to fight AHA, that enable control of bleeding, elimination of the inhibitor and reduction in mortality. Estimated mortality in the course of $\mathrm{AHA}$ in the 1980 s reached up to $42 \%$, while currently it does not exceed $12 \%$ [2].

The present paper discusses the principles of AHA diagnosis, the usage of hemostatic agents for bleeding control and prevention, eradication of FVIII inhibitor and patients' surveillance after achieving remission. Particular attention was paid to gynecological-obstetrics aspects related to the diagnosis and treatment of female patients with AHA.

\section{PATHOPHYSIOLOGY OF ACQUIRED HEMOPHILIA A}

The key problem in AHA are disorders of the immune system resulting in the production of antibodies that neutralize coagulant activity of factor VIII [3]. The mechanisms responsible for the breakdown of immune system in AHA have not been fully elucidated. The result of deficiency or complete absence of FVIII in the plasma is inhibition of thrombin generation and the lack of fibrin clot formation in sites of the vascular wall damage, which manifests as bleeding or hemorrhage.

The autoantibodies produced in acquired hemophilia A are mostly lgG1 and IgG4 class and bind to FVIII epitopes located on its $\mathrm{C} 2$ and $\mathrm{A} 2$ domains. The mechanism of their anticoagulant action relies on impairment of FVIII interac- 
tion with phospholipids (anti-C2 antibodies), disturbances in the formation of the intrinsic tenaze complex (anti-A2 antibodies) and most likely also on blocking the binding of FVIII to von Willebrand factor $[3,4]$.

The kinetics of FVIII interaction with autoantibodies in AHA is different from the kinetics of FVIII interaction with alloantibodies in congenital hemophilia A with inhibitors. While in congenital hemophilia $A$, alloantibodies completely abolish the FVIII activity in plasma, in acquired hemophilia A, even with a very high titer of autoantibodies, some residual plasma FVIII activity is detected. However, it does not protect AHA patients from severe bleeding [5]. Similarly to the FVIII alloantibodies, also autoantibodies to FVIII do not bind complement and do not cause allergic reactions.

\section{EPIDEMIOLOGY}

The annual incidence of acquired hemophilia $A$ is estimated at approximately 1.5 per million [6, 7]. The incidence of AHA increases with age, amounting to approximately 0.045/million among children under 16 and 14.7/million in people over 85 years of age [6]. The results of the multi-center, large-scale, pan-European, Web-based Registry $\mathrm{EACH} 2$ (European Acquired Hemophilia Registry) published several years ago, showed that the median age at the time of diagnosis of AHA is 73.9 years. In the age range of 2040 years, acquired hemophilia $A$ is more often detected in women than in men [8]. The increased incidence of AHA among young women is closely related to the period of pregnancy, especially to the first 6-12 months after delivery (see below-Acquired hemophilia associated with pregnancy and delivery $A$ ). In the older age groups, $\mathrm{AHA}$ is slightly more often detected in men [1].

Approximately half of patients with detectable autoantibodies against FVIII do not have underlying disorders. This form of AHA is called idiopathic. In approximately $35-40 \%$ of cases, AHA is associated with autoimmune disease, solid malignant tumors, hematologic tumors, allergic diseases or with a drug exposure (Tab. 1). The remaining $10-15 \%$ of cases of acquired hemophilia $A$ are detected, as already mentioned, among others, in young women up to 12 months after delivery.

\section{CLINICAL MANIFESTATION}

In most cases, AHA manifests as a sudden severe bleeding disorder which can lead to the death of a patient within a few weeks [1, 9]. Unlike congenital hemophilia A, spontaneous bleeding to the joints is very rare in AHA. Typical for acquired hemophilia $A$ are large subcutaneous hematomas (Fig. 1), mucosal bleeding (from the gastrointestinal and genitourinary tract), as well as bleeding from the wounds after surgical procedures and after tooth extraction (Tab. 2). It is worth noting that in AHA patients the most difficult to treat are hemorrhages from the wounds after surgical procedures. Therefore, invasive diagnostic and therapeutic procedures should be avoided in AHA patients [10]. Intracranial hemorrhages have a dramatic course and usually fail to be stopped on time. Fortunately, this type of bleeding is quite rare in patients with $\mathrm{AHA}$. Bleeding to the extremity muscles is very dangerous, because hematoma, located in a fascia-limited anatomical space, may exert a pressure on nerves and blood vessels causing their irreversible injury.

\section{ACQUIRED HEMOPHILIA A ASSOCIATED WITH PREGNANCY AND DELIVERY}

Acquired hemophilia $A$ is a rare complication of pregnancy and postpartum period. It is estimated that there is no more than one case of AHA in 350000 deliveries [7]. The disease may occur immediately after delivery, manifested by a severe uterine or vaginal hemorrhage,

Table 1. Underlying disorders predisposing to acquired hemophilia development [1]

\begin{tabular}{l|l}
\hline Underlying condition or disease & $\begin{array}{l}\text { Estimated incidence } \\
{[\%]}\end{array}$ \\
\hline $\begin{array}{l}\text { No underlying condition or disease } \\
\text { - idiopathic AHA }\end{array}$ & 51.9 \\
Malignant tumors & 11.8 \\
- Solid tumors & 8 \\
- Hematologic neoplasia & 3.8 \\
\hline Autoimmune diseases & 11.6 \\
- Rheumatoid arthritis & 4 \\
- Other diseases of connective tissue & 1.6 \\
- Systemic lupus erythematosus & 1 \\
- Autoimmune thyroiditis & 0.8 \\
- Sjögren syndrome & 0.6 \\
- Antiphospholipid syndrome & 0.4 \\
- Other autoimmune diseases & 3.8 \\
\hline Pregnancy and the period of 12 months & \\
after delivery & 8.4 \\
Infections & 3.8 \\
Relationship with drug use & 3.4 \\
- Beta-lactam antibiotics & 0.8 \\
- Clopidogrel & 0.6 \\
- Non-beta-lactam antibiotics & 0.4 \\
- Interferon & 0.4 \\
- Non-steroidal anti-inflammatory & \\
\hline drugs & 0.4 \\
- Amiodarone & 0.2 \\
- Rivastigmine & 0.2 \\
- Sunitinib & 0.2 \\
- Heparin & 0.2 \\
\hline MGUS & 2.6 \\
Polymyalgia rheumatica & 2.2 \\
Dermatological diseases & 1.4 \\
- Psoriasis & 0.6 \\
- Pemphigus & 0.6 \\
- Others & 0.2 \\
\hline Relationship with the transfusion of & \\
blood products & 0.8 \\
Other diseases & 8.2 \\
\hline MGS - & \\
\hline & \\
\hline
\end{tabular}

MGUS - monoclonal gammopathy of undetermined significance 

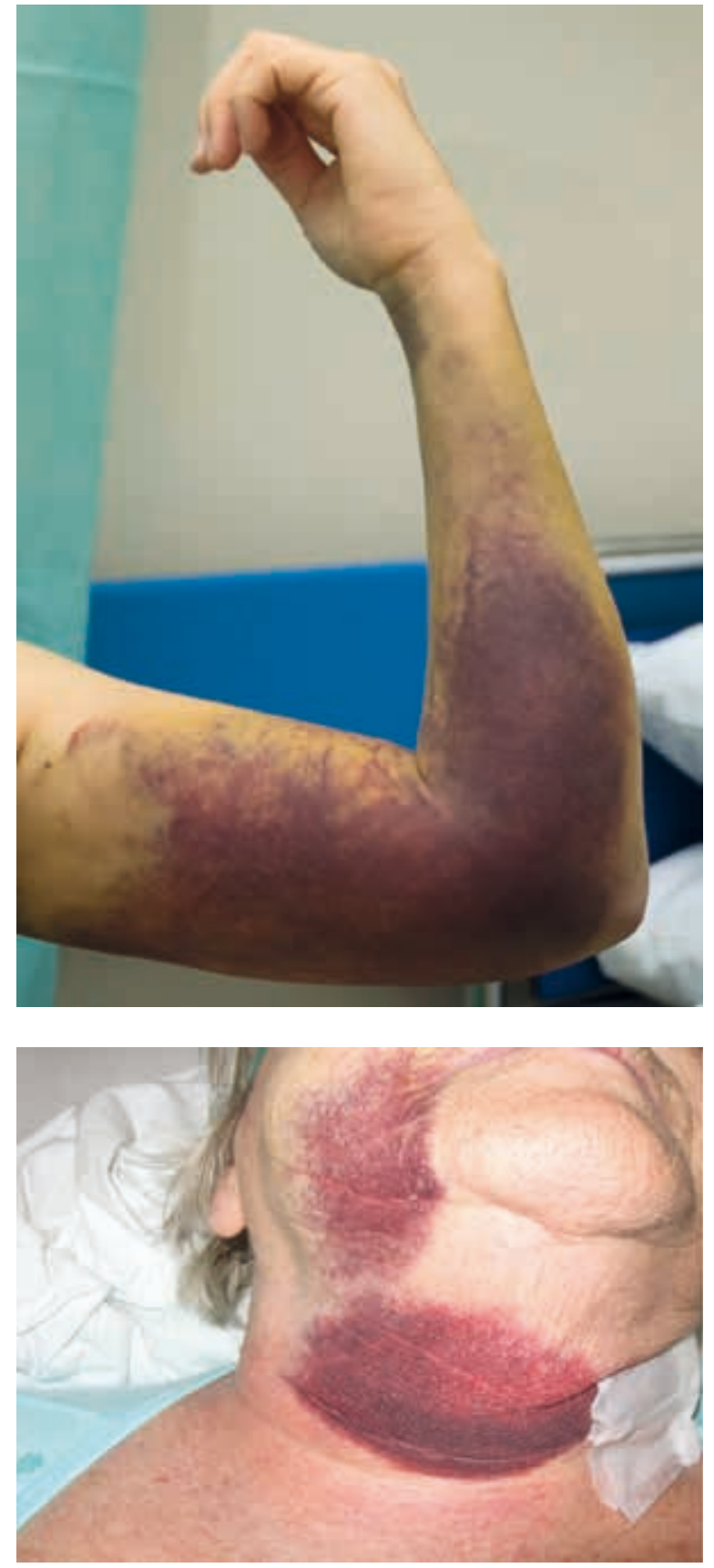

Figure 1. Large, spontaneous ecchymoses in 2 women with acquired hemophilia A (courtesy of the Author)

as well as develop up to 12 months after delivery, with extensive subcutaneous hematomas as the predominant symptom, accompanied by the more or less severe mucosal hemorrhages. The Italian Registry data, published in 2003 , indicate that acquired hemophilia usually develops postpartum, after a median of 60 days after delivery [11]. In the EACH2 Registry, acquired hemophilia was detected within 7 to 355 days (interquartile range [IQR] 21-120 days) (a median of 89 days) after delivery and the most common bleeding pattern was extensive subcutaneous
Table 2. The incidence of various types of bleeding in AHA [7]

\begin{tabular}{|l|l|}
\hline Type of bleeding & $\begin{array}{l}\text { Estimated } \\
\text { incidence [\%] }\end{array}$ \\
\hline Subcutaneous hematomas (often large) & 61 \\
\hline Muscle hematoma & 26 \\
\hline Subcutaneous only & 13 \\
\hline Gastrointestinal and intraabdominal & 13 \\
\hline Genitourinary & 5 \\
\hline Retroperitoneal & 5 \\
\hline Intraarticular & 4 \\
\hline Intracranial & $<2$ \\
\hline Requiring no hemostatic treatment & 20 \\
\hline
\end{tabular}

hemorrhages (45\%), mucosal bleeding (43\%), intramuscular hematomas or retroperitoneal hemorrhage (33\%). Only 2 women experienced bleeding into the joints [12]. In $45 \%$ of women bleeding was spontaneous, and in 55\% it occurred after trauma [12]. Post-traumatic bleeds were predominantly peripartum (34\% of all bleeds), and postsurgical ( $9 \%$ of all bleeds) [12]. Importantly, out of the 42 women included into the EACH2 Registry, in 8 (19\%) the symptoms of AHA were present antepartum [12]. Data from the $E A C H 2$ Registry reveal a significant delay in final diagnosis of pregnancy-associated and postpartum AHA. The median time between the first symptoms of abnormal bleeding and the diagnosis of AHA was 6 days (in every fourth women it was 21 days) [12].

Based on published data from about 20 years ago, it can be assumed that in about $70 \%$ of women with pregnancy-associated/postpartum AHA the spontaneous remission of the disease can be expected $[13,14]$. However, in the case of no remission and a severe course of bleeding disorder, an appropriate hemostatic and immunosuppressive treatment should be administered. In the EACH2 Registry, 39 out of 42 women with the pregnancy-associated or postpartum AHA required immunosuppressive treatment [12]. In the opinion of some of clinicians, eradication of the FVIII inhibitor with a use of immunosuppressive drugs in postpartum acquired hemophilia $A$ is often more difficult than in the idiopathic AHA or in AHA with other underlying conditions [7]. This opinion contradicts the results of the EACH2 Registry, which show that the use of corticosteroid monotherapy led to the eradication of FVIII inhibitor in $74 \%$ of women with pregnancy-associated $\mathrm{AHA}$, i.e. at no lesser percentage than in other groups of AHA patients [12].

In the EACH2 Registry, the primigravida accounted for $74 \%$ of all women who developed AHA associated with pregnancy and delivery [12]. Additionally, all women with pregnancy-associated or postpartum AHA in the EACH2 Registry were free of other serious diseases or clinical conditions 
that could explain the occurrence of AHA [12]. These data are consistent with the results of previous studies. The final assessment of the health status in women with pregnancy-associated or postpartum $\mathrm{AHA}$, in the EACH2 Registry follow-up was performed at a median of 406 days (IQR 221-817 days) from the onset of AHA symptoms [12]. At that time, all women were alive and 36 out of 42 (86\%) achieved complete remission. These results confirm a better prognosis in women with pregnancy-associated or postpartum AHA as compared to women with AHA associated with other underlying conditions. [12]. The $\mathrm{EACH} 2$ registry does not provide information on subsequent pregnancies in this group of 42 women.

One paper describes a decrease in the FVIII activity in the blood of a neonate born to a woman with AHA, following transplacental transfer of FVIII antibodies [15].
In the newborn occurred a hemorrhage requiring hemostatic treatment.

\section{LABORATORY FINDINGS}

In a person with $\mathrm{AHA}$, laboratory tests typically show a 2-3-fold prolongation of activated partial thromboplastin time (aPTT) with normal prothrombin time (PT), thrombin time (TT), closure time (CT) in PFA-100/-200 ${ }^{\circledR}$ (platelet function analyzer), normal platelet count and the plasma fibrinogen level within the normal range (Tab. 3). Such a combination of laboratory test results is also found only in congenital deficiency of clotting factors VIII, IX, XI, $\mathrm{XII}$ and in the presence of lupus anticoagulant (LA) in the test plasma. However, LA is not directed against the clotting factor but against phospholipids and does not trigger bleeding but predisposes to thrombosis. If prolonged aPTT

Table 3. Differential diagnosis of prolonged aPTT

\begin{tabular}{|c|c|c|c|c|c|c|c|c|c|c|c|c|c|}
\hline \multirow{2}{*}{$\begin{array}{l}\text { Condition } \\
\text { Parameter }\end{array}$} & \multicolumn{3}{|c|}{$\begin{array}{l}\text { Coagulation } \\
\text { times }\end{array}$} & \multirow{2}{*}{ Platelets } & \multirow{2}{*}{ FIB } & \multicolumn{5}{|c|}{ Clotting factors activity } & \multirow{2}{*}{$\begin{array}{l}\text { Mixing } \\
\text { test }^{*}\end{array}$} & \multirow{2}{*}{$\begin{array}{l}\text { Inhibitor } \\
>0.5 \mathrm{BU} / \mathrm{mL}\end{array}$} & \multirow{2}{*}{$\begin{array}{l}\text { Clinical } \\
\text { presentation }\end{array}$} \\
\hline & APTT & PT & TT & & & FVIII & FIX & FXI & FXII & VWF & & & \\
\hline Acquired hemophilia A & $\uparrow$ & $\mathrm{N}$ & $\mathrm{N}$ & $\mathrm{N}$ & $\mathrm{N}$ & $\downarrow$ & $\mathrm{N}$ & $\mathrm{N}$ & $\mathrm{N}$ & $\mathrm{N}$ & positive & $\begin{array}{l}\text { FVIII inhibitor } \\
\text { present }\end{array}$ & $\begin{array}{l}\text { sudden onset of } \\
\text { bleeding disorder }\end{array}$ \\
\hline Hemophilia A & $\uparrow$ & $\mathrm{N}$ & $\mathrm{N}$ & $\mathrm{N}$ & $\mathrm{N}$ & $\downarrow$ & $\mathrm{N}$ & $\mathrm{N}$ & $\mathrm{N}$ & $\mathrm{N}$ & negative & absent & bleeding disorder \\
\hline $\begin{array}{l}\text { Hemophilia A with } \\
\text { inhibitors }\end{array}$ & $\uparrow$ & $\mathrm{N}$ & $\mathrm{N}$ & $\mathrm{N}$ & $\mathrm{N}$ & $\downarrow$ & $\mathrm{N}$ & $\mathrm{N}$ & $\mathrm{N}$ & $\mathrm{N}$ & positive & $\begin{array}{l}\text { FVIII inhibitor } \\
\text { present }\end{array}$ & $\begin{array}{l}\text { previous treatment } \\
\text { ineffective }\end{array}$ \\
\hline $\begin{array}{l}\text { von Willebrand disease } \\
\text { type } 3\end{array}$ & $\uparrow$ & $\mathrm{N}$ & $\mathrm{N}$ & $\mathrm{N}$ & $\mathrm{N}$ & $\downarrow$ & $\mathrm{N}$ & $\mathrm{N}$ & $\mathrm{N}$ & $\downarrow$ & negative & absent & bleeding disorder \\
\hline Hemophilia B & $\uparrow$ & $\mathrm{N}$ & $\mathrm{N}$ & $\mathrm{N}$ & $\mathrm{N}$ & $\mathrm{N}$ & $\downarrow$ & $\mathrm{N}$ & $\mathrm{N}$ & $\mathrm{N}$ & negative & absent & bleeding disorder \\
\hline $\begin{array}{l}\text { Hemophilia B with } \\
\text { inhibitors }\end{array}$ & $\uparrow$ & $\mathrm{N}$ & $\mathrm{N}$ & $\mathrm{N}$ & $\mathrm{N}$ & $\mathrm{N}$ & $\downarrow$ & $\mathrm{N}$ & $\mathrm{N}$ & $\mathrm{N}$ & positive & $\begin{array}{l}\text { FIX inhibitor } \\
\text { present }\end{array}$ & $\begin{array}{l}\text { previous treatment } \\
\text { ineffective }\end{array}$ \\
\hline FXI deficiency & $\uparrow$ & $\mathrm{N}$ & $\mathrm{N}$ & $\mathrm{N}$ & $\mathrm{N}$ & $\mathrm{N}$ & $\mathrm{N}$ & $\downarrow$ & $\mathrm{N}$ & $\mathrm{N}$ & negative & absent & bleeding disorder \\
\hline FXII deficiency & $\uparrow$ & $\mathrm{N}$ & $\mathrm{N}$ & $\mathrm{N}$ & $\mathrm{N}$ & $\mathrm{N}$ & $\mathrm{N}$ & $\mathrm{N}$ & $\downarrow$ & $\mathrm{N}$ & negative & absent & $\begin{array}{l}\text { no symptoms of } \\
\text { bleeding disorder }\end{array}$ \\
\hline $\begin{array}{l}\text { Lupus anticoagulant } \\
\text { (LA) }\end{array}$ & $\uparrow$ & $\mathrm{N}$ & $\mathrm{N}$ & $\mathrm{N}$ & $\mathrm{N}$ & $\begin{array}{l}\mathrm{N} \\
\text { or } \\
\downarrow \#\end{array}$ & $\begin{array}{l}\mathrm{N} \\
\text { or } \\
\downarrow \#\end{array}$ & $\begin{array}{l}\mathrm{N} \\
\text { or } \\
\downarrow \#\end{array}$ & $\begin{array}{l}\mathrm{N} \\
\text { or } \\
\downarrow \#\end{array}$ & $\mathrm{~N}$ & positive & absent ${ }^{*}$ & $\begin{array}{l}\text { no symptoms of } \\
\text { bleeding disorder } \\
\text { /sometimes } \\
\text { thrombosis }\end{array}$ \\
\hline Heparin contamination & $\uparrow$ & $\begin{array}{l}\mathrm{N} \\
\text { or } \\
\uparrow\end{array}$ & $\uparrow$ & $\mathrm{N}$ & $\mathrm{N}$ & $\begin{array}{l}\mathrm{N} \\
\text { or } \\
\downarrow\end{array}$ & $\begin{array}{l}\mathrm{N} \\
\text { or } \\
\downarrow\end{array}$ & $\begin{array}{l}\mathrm{N} \\
\text { or } \\
\downarrow\end{array}$ & $\begin{array}{l}N \\
\text { or } \\
\downarrow\end{array}$ & $\mathrm{N}$ & positive & absent $^{¥}$ & $\begin{array}{l}\text { possible symptoms } \\
\text { of bleeding disorder }\end{array}$ \\
\hline $\begin{array}{l}\text { Deficiency of Vitamin K } \\
\text { dependent factors/ } \\
\text { VKA overdose }\end{array}$ & $\begin{array}{l}\mathrm{N} \\
\text { or } \\
\uparrow\end{array}$ & $\uparrow$ & $\begin{array}{l}N \\
\text { or } \\
\uparrow\end{array}$ & $\mathrm{N}$ & $\begin{array}{l}\mathrm{N} \\
\text { or } \\
\downarrow\end{array}$ & $\begin{array}{l}N \\
\text { or } \\
\downarrow\end{array}$ & $\downarrow$ & $\begin{array}{l}\mathrm{N} \\
\text { or } \\
\downarrow\end{array}$ & $\begin{array}{l}N \\
\text { or } \\
\downarrow\end{array}$ & $\mathrm{N}$ & negative & absent & $\begin{array}{l}\text { possible symptoms } \\
\text { of bleeding disorder }\end{array}$ \\
\hline Severe liver diseases & $\uparrow$ & $\uparrow$ & $\uparrow$ & Nor $\downarrow$ & $\downarrow$ & $\begin{array}{l}\mathrm{N} \\
\text { or } \\
\downarrow\end{array}$ & $\begin{array}{l}N \\
\text { or } \\
\downarrow\end{array}$ & $\begin{array}{l}N \\
\text { or } \\
\downarrow\end{array}$ & $\begin{array}{l}N \\
\text { or } \\
\downarrow\end{array}$ & $\mathrm{N}$ & negative & absent & $\begin{array}{l}\text { possible symptoms } \\
\text { of bleeding disorder }\end{array}$ \\
\hline DIC & $\begin{array}{l}\mathrm{N} \\
\text { or } \uparrow\end{array}$ & $\begin{array}{l}\mathrm{N} \\
\text { or } \\
\uparrow\end{array}$ & $\begin{array}{l}N \\
\text { or } \\
\uparrow\end{array}$ & $\downarrow$ & $\begin{array}{l}\mathrm{N} \\
\text { or } \\
\downarrow\end{array}$ & $\begin{array}{l}\mathrm{N} \\
\text { or } \\
\downarrow\end{array}$ & $\begin{array}{l}\mathrm{N} \\
\text { or } \\
\downarrow\end{array}$ & $\begin{array}{l}N \\
\text { or } \\
\downarrow\end{array}$ & $\begin{array}{l}N \\
\text { or } \\
\downarrow\end{array}$ & $\begin{array}{l}\mathrm{N} \\
\text { or } \\
\downarrow\end{array}$ & negative & absent & $\begin{array}{l}\text { possible symptoms } \\
\text { of bleeding disorder }\end{array}$ \\
\hline
\end{tabular}

*) a positive mixing test means the presence of an inhibitor; $\#$ ) lupus anticoagulant may interfere with assays for coagulation factors activity resulting in falsely lowered or elevated values; ${ }^{*}$ ) lupus anticoagulant and heparins (to a much lesser extent) may interfere with the assays for inhibitor resulting in falsely positive results (inhibitor titer $>0.5 \mathrm{BU} / \mathrm{mL}$ ); $\uparrow —$ value above the reference range; $\downarrow$ - value below the reference range; aPTT — activated partial thromboplastin time; assays repeated in the samples of patient's diluted plasma allow to exclude the effect of LA; DIC — disseminated intravascular coagulation; F — factor; FIB - fibrinogen; LA - lupus anticoagulant; $\mathrm{N}$ - value within the reference range; PT — prothrombin time; TT — thrombin time; VKA — vitamin K antagonist; VWF — von Willebrand factor 
is caused by a presence of unfractionated heparin in the blood sample, the thrombin time is significantly prolonged or non-determinable. Confirmation of the presence of circulating anticoagulant is prolonged aPTT in a mixture of equal volumes of the tested plasma and normal plasma (no aPTT correction, i.e. a positive test for the presence of circulating anticoagulant). A test for the presence of circulating anticoagulant is positive with either FVIII inhibitor or LA or an inhibitor directed against coagulation factors other than FVIII. Therefore, factor VIII activity should be measured, to confirm that the circulating anticoagulant is directed against FVIII. FVIII activity in healthy individuals is comprised in the range of $50-150 \mathrm{IU} / \mathrm{dL}(50-150 \%$ of the normal), while in AHA it is in the range of $0-20 \mathrm{IU} / \mathrm{dL}$. The last step to the laboratory diagnosis of the presence of FVIII inhibitor is a measurement of its titer expressed in Bethesda units (BU/mL) [16-18].

It is worth emphasizing that laboratory diagnostics for the FVIII inhibitor should be carried out in blood samples taken before initiation of hemostatic treatment (see below). Following administration of hemostatic agent, some patients with AHA shorten or even normalize aPTT, which falsifies the results of subsequent laboratory tests and may lead to erroneous exclusion of AHA as a cause of hemorrhage (Fig. 2).

As the diagnostic process of AHA combines the analysis of the clinical presentation and the results of specialistic laboratory tests, the authors of this paper indicate the need for close cooperation between the medical team and the laboratory diagnostics team in order to optimize this process.

\section{MANAGEMENT}

The treatment strategy in patients with acquired hemophilia A has two main goals: immediate, which is control and prophylaxis of bleeding, and the ultimate one, which is inhibitor eradication i.e. complete remission of AHA, often meaning the cure (Fig. 2). In rare cases of AHA without accompanying symptoms of bleeding disorder, the management will be limited to the elimination of the inhibitor. Prompt diagnosis and appropriate treatment of comorbidities may increase the chance to achieve AHA remission.

\section{HEMOSTATIC AGENTS}

Unlike congenital hemophilia $A$, there is no close correlation between plasma FVIII activity and the severity of bleeding in AHA. Therefore, even with a very low inhibitor titer and a few to dozen percent of residual FVIII plasma activity, the best way to stop bleeding in AHA is the use of so-called by-passing agents (BPA), i.e. recombinant activated factor VII ( $\mathrm{FFVIIa)} \mathrm{or} \mathrm{activated} \mathrm{prothrombin} \mathrm{complex} \mathrm{con-}$ centrate (aPCC), but not the administration of human factor VIII products (hFVIII) (Tab. 4). The BPA activate blood clotting, bypassing the factor VIII-dependent stage, hence their name: bypassing agents. The efficacy of rFVIla and aPCC in control of bleeding in acquired hemophilia A has been confirmed by the results of clinical trials [1, 19-24]. The greatest disadvantage of both drugs is the lack of laboratory tests to assess their efficacy. The risk of thrombotic complications of both drugs should not be neglected, especially in elderly people with concomitant risk factors for venous thromboembolism (VTE) and/or arterial thromboembolism (ATE). Once the remission is achieved, i.e. the inhibitor is eliminated, the use of BPA should be immediately discontinued. Anticoagulants are contraindicated in patients with AHA, however, after elimination of the inhibitor, they can be safely used if needed.

In case of a lack of clinical efficacy of rFVIla and aPCC monotherapies, alternating rFVIla and aPCC (so-called sequential therapy) may be used. Sequential therapy exposes patients to the risk of thromboembolic complications. Therefore, it should be only used by a hematologist experienced in the treatment of patients with bleeding disorders $[25,26]$.

Recently, a new medication for bleeding control in AHA recombinant porcine factor VIII (rpFVIII) has been introduced $[27,28]$. This agent shows the coagulation activity similar to human FVIII, and at the same time, in most cases is not neutralized by the antibodies against human FVIII. The biggest advantage of rpFVIII as compared to rFVIla and aPCC is the availability of laboratory testing of factor VIII activity in plasma of AHA patients and possibility to adjust rpFVIII dose based on the results of these measurements. Before switching from BPA to $\mathrm{rpFVIII,} \mathrm{the} \mathrm{plasma} \mathrm{of} \mathrm{the} \mathrm{AHA} \mathrm{patient} \mathrm{should} \mathrm{be} \mathrm{tested} \mathrm{for}$ the presence of cross-reactive antibodies, that neutralize both $\mathrm{hFVIII} \mathrm{and} \mathrm{rpFVIII.} \mathrm{If} \mathrm{such} \mathrm{antibodies} \mathrm{are} \mathrm{present,} \mathrm{very} \mathrm{high} \mathrm{doses}$ of rpFVIII must be administered and it should be ensured that adequate (hemostatic) FVIII activity in the plasma has been reached. At the high titer of anti-porcine FVIII antibodies, the use of rpFVIII may not be effective. In Poland rpFVIII has been approved by regulatory authorities, but so far it is not reimbursed by the National Health Fund (NFZ).

In exceptional cases of AHA with a low titer of FVIII inhibitor and with a mild bleeding, the use of human FVIII concentrate or desmopressin under control of plasma FVIII activity may be effective (it is usually recommended to maintain FVIII activity above $50 \mathrm{IU} / \mathrm{dL}$ ). Data from the $\mathrm{EACH} 2$ Registry indicate that BPA control bleeding much more effectively as compared to hFVIII concentrate and desmopressin $[2,27,29,30]$.

The drug that effectively controls mucosal bleeding is tranexamic acid (TxA). In adults, it is administered at a dose of $1.0 \mathrm{~g}$ every 8 hours, orally or intravenously (local administration is less common). The drug is contraindicated in people with active bleeding from urinary tract due to the risk of clot formation and block of urine outflow. In AHA, 


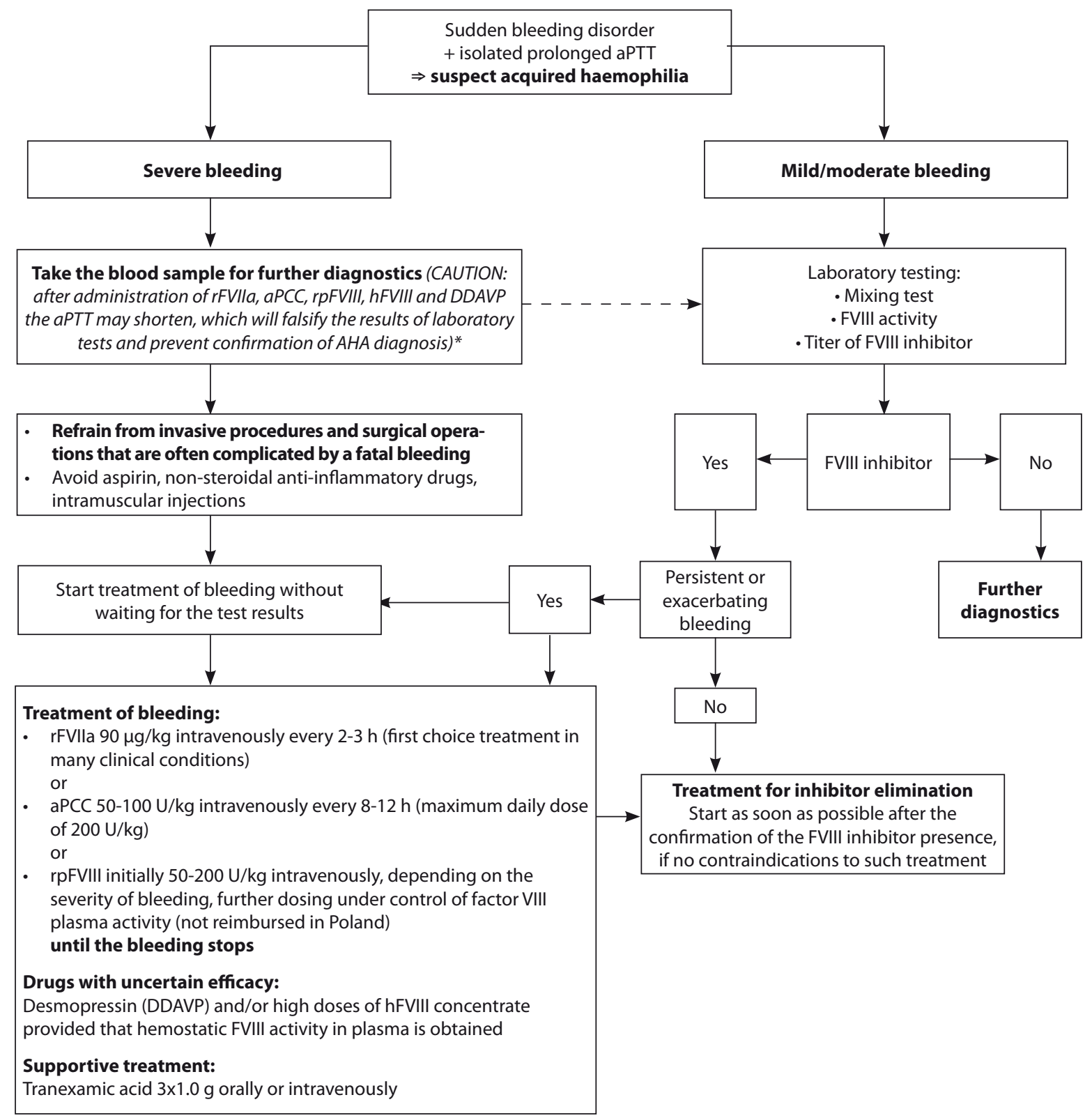

aPCC — activated prothrombin complex concentrate; aPTT — activated partial thromboplastin time; hFVIII — human FVIII; FVIII — factor VIII; rFVIIa — recombinant activated factor VII; rpFVIII — recombinant porcine factor VIII;

*) rFVIla, aPCC, hFVIII and DDAVP concentrates are available free of charge for patients with a confirmed diagnosis of AHA in Regional Blood Donation and Transfusion Centres (RCKiKs); the list of RCKiK in Poland is included in the Supplement 2 to this paper

Figure 2. Algorithm for management of acquired hemophilia A [10]

tranexamic acid has a status of a supportive treatment. It can be used concomitantly with rFVIla, aPCC, hFVIII and rpFVIII. The previously raised concerns about a significant increase in the risk of thromboembolic complications in patients receiving simultaneously aPCC and TxA have been dispelled after publication of positive experiences from several research teams [31, 32].

Another treatment option used in AHA patients is the immunoadsorption combined with intravenous transfusion of high doses of hFVIII concentrate under the control of plasma FVIII activity [2]. According to the knowledge of the authors of this paper, no immunoadsorption procedures are performed in Poland, and literature data indicate that this therapeutic option is available in only a few centers in Europe [2].

Therapeutic management for bleeding control in a woman with peripartum AHA is the same as in the other groups of AHA patients. Data from the EACH2 Registry showed high efficacy of BPA in bleeding control in the course of AHA associated with pregnancy and delivery [12].

Although, according to the EACH2 Registry data, BPA can effectively stop bleeding in more than $93 \%$ of patients with $\mathrm{AHA}$, it is recommended to avoid elective invasive pro- 


\begin{tabular}{|c|c|}
\hline Drug & Posology \\
\hline rFVIla & $\begin{array}{l}\geq 90 \mu \mathrm{g} / \mathrm{kg} \text { i.v. every } 2-3 \mathrm{~h} \text { in case of severe bleeding, with an option to subsequently extend dosing } \\
\text { intervals up to } 4-6-12-24 \mathrm{~h}\end{array}$ \\
\hline $\mathrm{aPCC}$ & $50-100 \mathrm{U} / \mathrm{kg}$ i.v. every $8-12 \mathrm{~h}$ (maximum of $200 \mathrm{U} / \mathrm{kg} /$ day) \\
\hline rpFVIII & $\begin{array}{l}\text { If anti-rpFVIII antibodies absent: initially } 50-100 \mathrm{U} / \mathrm{kg} \text {, further dosing under the control of plasma FVIII } \\
\text { activity*; } \\
\text { If anti-rpFVIII antibodies present: initially } 200 \mathrm{U} / \mathrm{kg} \text { in the severe bleeding or } 50-100 \mathrm{U} / \mathrm{kg} \text { in the milder } \\
\text { bleeding, further dosing under the control of plasma FVIII activity*; }\end{array}$ \\
\hline Human factor VIII+ concentrate & $\begin{array}{l}50-100 \mathrm{U} / \mathrm{kg} \text { i.v. every } 8-12 \mathrm{~h} \text { or in a continuous intravenous infusion under the control of plasma factor } \\
\text { VIII activity }\end{array}$ \\
\hline Desmopressin ${ }^{+}$ & $\begin{array}{l}0.3-0.4 \mathrm{mg} / \mathrm{kg} \text { (in } 100 \mathrm{~mL} 0.9 \% \mathrm{NaCl} \text { ) in an intravenous infusion over a minimum of } 30 \mathrm{~min} \text {, repeated, if } \\
\text { necessary, every } 24 \mathrm{~h} \text { under the control of plasma factor VIII activity }\end{array}$ \\
\hline Tranexamic acid (supportive treatment) & $1.0 \mathrm{~g}$ every $8 \mathrm{~h}$ orally or intravenously \\
\hline
\end{tabular}

cedures and surgical operations in this group of patients [2]. This recommendation comes from the observation that despite the use of optimal anti-hemorrhagic treatment, invasive procedures (including catheterization of large blood vessels) in patients with AHA may be complicated by a massive, uncontrolled, potentially life-threatening bleeding. However, if the delay in conducting an invasive procedure or surgical operation is medically unacceptable, the management for perioperative period should be consulted with a hematologist who has expertise in the treatment of bleeding disorders. The BPA posology in this situation does not differ from the BPA posology for the invasive procedures conducted in patients with congenital hemophilia A with FVIII inhibitors [25].

According to regulations of the National Program for Treatment of Hemophilia and Allied Bleeding Disorders (2019-2023) in Poland, rFVIla, aPCC, hFVIII concentrates, as well as desmopressin are available free of charge for the treatment of patients with a confirmed AHA diagnosis from the Regional Blood Donation and Transfusion Centers (Regionalne Centrum Krwiodawstwa i Krwiolecznictwa, RCKiK) [33]. The list of RCKiK is included in Appendix 1 to this article.

\section{INHIBITOR ERADICATION}

In order to eliminate autoantibodies against FVIII, immunosuppressive drugs are used [2, 9, 11, 27, 29, 30, 34]. Immunosuppressive treatment should be initiated as soon as the diagnosis of acquired hemophilia A is confirmed, although the possible contraindications to this type of treatment should never be ignored. It also should not be forgotten that immunosuppressive therapy carries a considerable risk of side effects, including myelosuppression and serious infections, which are particularly dangerous in the elderly patients, who constitute the majority of patients with acquired hemophilia A. Nonetheless, in the EACH2 Registry, also three young women with pregnancy-associated or postpartum AHA developed complications after immunosuppression - two patients had post-steroid diabetes, and one suffered from infection [12].

The majority of authors recommends corticosteroids or corticosteroids with cyclophosphamide in the first-line of immunosuppressive therapy (Tab. 5) [1, 2, 9, 11, 27, 29, 30, 34-39]. There is usually given prednisone/prednisolone orally at a dose of $1 \mathrm{mg} / \mathrm{kg} /$ day for 4-6 weeks in monotherapy or in combination with cyclophosphamide also orally at a dose of $1-2 \mathrm{mg} / \mathrm{kg} /$ day, for a maximum of 6 weeks. With the use of such treatment regimen remission, defined as an increase in FVIII activity above $50 \mathrm{IU} / \mathrm{dL}$ and lowering the inhibitor titer below the detection threshold, i.e. $0.6 \mathrm{BU} / \mathrm{mL}$, is achieved in about $70 \%$ of patients. In the EACH2 Registry, at the end of follow-up, after a median of 258 days (IQR 74-685 days) $72.6 \%$ of patients with AHA achieved complete remission of disease, $11.8 \%$ of patients normalized FVIII activity, but continued immunosuppressive therapy, $10 \%$ of patients failed to eliminate FVIII inhibitor, and in $6.6 \%$ of patients the status of FVIII inhibitor was unknown [1].

In patients who have not achieved remission after 4-6 weeks of immunosuppressive treatment, a second attempt to eliminate the inhibitor is recommended. Currently, the prevailing opinion is that in the second-line of immunosuppressive treatment it is worth using rituximab at a standard dose of $375 \mathrm{mg} / \mathrm{m} 2 /$ week for the consecutive 4 weeks (smaller doses have also been successfully used) $[40,41]$. Unfortunately, the use of rituximab in patients with AHA is not covered by the NFZ reimbursement in Poland. Other therapeutic options include the use of ciclosporin, tacrolimus, azathioprine, vincristine and mycophenolate mofetil, as well as a combination therapy including several immunosuppressants administered concomitantly, 
Table 5. Drugs used to eliminate autoantibodies against Factor VIII

\begin{tabular}{|c|c|}
\hline Drug & Suggested posology \\
\hline Prednisone/Prednisolone* & $1 \mathrm{mg} / \mathrm{kg} / \mathrm{d}$ orally for a maximum of $4-6$ weeks \\
\hline Cyclophosphamide* & $1.5-2.0 \mathrm{mg} / \mathrm{kg} / \mathrm{d}$ orally for a maximum of $4-6$ weeks \\
\hline Rituximab & $375 \mathrm{mg} / \mathrm{m}^{2}$ intravenously once a week (for $\geq 4$ consecutive weeks) (lower doses may be effective) \\
\hline Azathioprine & $2 \mathrm{mg} / \mathrm{kg} / \mathrm{d}$ orally (maximum daily dose of $150 \mathrm{mg}$ ) \\
\hline Cyclosporine & $\begin{array}{l}5 \mathrm{mg} / \mathrm{kg} / \mathrm{d} \text { orally for } 6 \text { days, followed by } 2.5-3 \mathrm{mg} / \mathrm{kg} / \mathrm{d} \text { orally under the control of serum concentration, which should } \\
\text { be } 100-200 \mathrm{ng} / \mathrm{mL}\end{array}$ \\
\hline $\mathrm{IVlg}^{+}$ & $0.3-0.4 \mathrm{~g} / \mathrm{kg} / \mathrm{d}$ intravenously for 5 days or $1 \mathrm{~g} / \mathrm{kg} / \mathrm{d}$ intravenously for 2 days \\
\hline Vincristine $\#$ & $1 \mathrm{mg} / \mathrm{m}^{2}$ intravenously (maximum single dose of $2 \mathrm{mg}$ ), $4-6$ infusions in 7-day intervals (maximum total dose of $6 \mathrm{mg}$ ) \\
\hline 2-CDA & $0.1 \mathrm{mg} / \mathrm{kg}$ in a 24 -hour infusion over 7 days or $0.14 \mathrm{mg} / \mathrm{kg}$ in a 2-hour intravenous infusion for 5 days \\
\hline Mycophenolate mofetil & $1000 \mathrm{mg}$ every $12 \mathrm{~h}$ orally for at least 3-4 weeks \\
\hline $\begin{array}{l}\text { Immunotolerance } \\
\text { (Budapest Program) }\end{array}$ & $\begin{array}{l}\text { FVIII intravenously } 30 \mathrm{IU} / \mathrm{kg} \text { every } 24 \mathrm{~h} \text { for the first week, } 20 \mathrm{IU} / \mathrm{kg} \text { every } 24 \mathrm{~h} \text { for the second week and } 15 \mathrm{IU} / \mathrm{kg} \text { every } \\
24 \mathrm{~h} \text { for the third week } \\
+ \text { cyclophosphamide (intravenously) } 200 \mathrm{mg} / \mathrm{d} \text { for a total dose of } 2-3 \mathrm{~g} \\
+ \text { methylprednisolone (intravenously) } 100 \mathrm{mg} / \mathrm{d} \text { for the first week and in gradually decreasing doses over the next } \\
\text { two weeks }\end{array}$ \\
\hline
\end{tabular}

") in the first-line treatment it is recommended to use prednisone or prednisolone in a combination with cyclophosphamide at the doses shown in the table; ") most often in a combination with cyclophosphamide and/or prednisone; ${ }^{+}$) monotherapy is not recommended; 2-CDA - 2-chlorodeoxyadenosine; $d$ - day; IVlg-- intravenous immunoglobulins; FVIII — factor VIII

e.g. cyclophosphamide + vincristine + prednisone [42-46]. In the opinion of some investigators, the combined use of immunosuppressive drugs and intravenous injections of hFVIII concentrate contributes to the shortening of time needed to eliminate the inhibitor. This treatment regimen, elaborated by the Hungarian authors and based on the immunotolerance programs used in congenital hemophilia A with alloantibodies developed against FVIII, is referred to as the Budapest Program (Tab. 5) [47].

The management targeted on elimination of FVIII inhibitor in a woman with the postpartum AHA is based on the same principles as in the other groups of AHA patients with one exception; in young patients at childbearing age, the use of cytotoxic drugs (e.g. cyclophosphamide) is avoided [2, 12]. Data from the EACH2 Registry showed a high efficacy of immunosuppressive drugs (including corticosteroid monotherapy) in eliminating FVIII inhibitor in AHA associated with pregnancy and delivery [12].

\section{FOLLOW-UP AFTER COMPLETE REMISSION}

After achieving remission, the patient should be followed-up for two years for possible relapse [2, 27, 29, 30]. FVIII activity should be measured once a month for the first six months after remission, then every 2-3 months for the next six months and then every 6 months for the following year. It is estimated that AHA relapse occurs in about $20 \%$ of patients who achieved remission after the first course of immunosuppressive treatment [5]. In such cases, second attempt to eliminate the inhibitor should be taken and the same immunosuppressive treatment that provided the first remission can be used. If immunosup- pressive therapy completely fails, a careful monitoring and treatment of hemorrhage is the only management option. In case of high severity of bleeding disorder, prolonged prophylaxis with use of inhibitor bypassing agents can be considered $[23,48]$.

Older studies did not show AHA recurrence in subsequent pregnancies, but recently such cases have been described [14, 49-51]. Therefore, if a woman with a history of pregnancy-associated or postpartum AHA is planning another pregnancy, she should be covered by a specialist care of gynecologist and hematologist, to ensure monitoring of hemostasis system for prompt detection of FVIII inhibitor recurrence.

\section{PROGNOSIS FOR SURVIVAL IN ACQUIRED HEMOPHILIA A}

Prognosis in AHA depends on the type and course of comorbidities, on the severity of bleeding and on the time to diagnosis and initiation of appropriate anti-hemorrhagic and immunosuppressive treatment [30].

In the EACH2 Registry, the survival analysis included a group of 331 patients with AHA. The median follow-up was 258 days (IQR 74-685 days). The final analysis showed that $61.2 \%$ of patients survived, $27.9 \%$ died, with a median of time between AHA diagnosis and death being 75 days (IQR 25-240 days). For $10.9 \%$ of patients the survival status remained unknown [1]. Data from this registry identified the independent risk factors for death in AHA patients: older age, lower hemoglobin level at the AHA diagnosis, concomitant malignancy, and failure to eliminate FVIII inhibitor [1]. In contrast, gender, FVIII activity at the time of AHA diagnosis and 
FVIII inhibitor titer at the time of AHA diagnosis did not show a statistically significant effect on the patients' survival [1].

Death due to a bleeding occurred in $3 \%$ of patients followed in the EACH2 Registry [1]. Interestingly, excessive bleeding was the cause of (only) $16 \%$ of all deaths in the analyzed group. The most frequent cause of death in this group was underlying disease, responsible for $45 \%$ of all deaths ( $9 \%$ of patients in the follow-up of the EACH2 Registry). Complications of immunosuppression, similarly to hemorrhages, were responsible for deaths of $3 \%$ of all patients followed in the EACH2 Registry.

\section{SUMMARY}

The cardinal principles of diagnostic and therapeutic approach in AHA are presented below:

1. A sudden onset of bleeding disorder accompanied by an isolated prolonged aPTT in a person with no previous history of bleeding should raise a suspicion of acquired hemophilia A.

2. Acquired hemophilia A affects, most of all, elderly people and patients with autoimmune diseases or malignancies, but young women up to 12 months after delivery are also at higher risk of developing AHA.

3. In young women diagnosed with autoimmune disease, the possibility of occurrence of $\mathrm{AHA}$ in the peripartum period should be taken into consideration and a patient should be offered a care of the facility capable to monitor hemostasis system throughout a pregnancy, delivery and postpartum period.

4. Irrespective of age, in women with autoimmune disease and malignancy that experience prolonged uterine or vaginal bleeding, the possibility of AHA should be considered and basic coagulation tests should be done. Once the isolated prolonged aPTT is found, the diagnostic panel for AHA should be conducted.

5. Although AHA is classified as a severe bleeding disorder, in about $30 \%$ of cases the symptoms of the disease are occult or scarce, which may hinder establishing promptly a proper diagnosis.

6. Laboratories of hemostasis should develop and apply in their daily practice the algorithms for detection of isolated prolonged aPTT. This algorithms should include the clinical presentation (presence or absence of symptoms of bleeding disorder) and the mixing test of examined and normal plasma for an aPTT correction, which indicates the presence or absence of a circulating anticoagulant.

7. Invasive procedures and surgical operations expose AHA patients to the risk of uncontrolled hemorrhage, even when using appropriate hemostatic drugs at proper doses. Therefore, it is recommended to avoid all elective invasive procedures in this group of patients until the
FVIII inhibitor is eliminated. If a delay in invasive procedure is not possible, the anti-hemorrhagic management should be decided by a hematologist experienced in the treatment of bleeding disorders.

8. The strategy for management of AHA patient includes bleeding control, elimination of FVIII inhibitor and treatment of comorbidities, first of all those that predispose to a development of FVIII inhibitor.

9. The first-line hemostatic drugs are inhibitor bypassing agents, i.e. rFVIla and aPCC. Desmopressin and human factor VIII concentrate are less effective than bypassing agents. Recombinant porcine factor VIII is not reimbursed by National Health Fund in Poland. Tranexamic acid is a supportive drug. Posology of hemostatic drugs is shown it the Table 4.

10. In case of a lack of clinical efficacy of rFVlla and aPCC monotherapies, alternating rFVIla and aPCC (so-called sequential therapy) may be used. Sequential therapy exposes patients to the risk of thromboembolic complications. Therefore, it should be only used by a hematologist experienced in the treatment of patients with bleeding disorders.

11. The FVIII inhibitor should be eliminated by using immunosuppressive drugs in every patient with AHA (unless the inhibitor has been eliminated spontaneously). Immunosuppressive treatment should be initiated as soon as possible after the AHA is diagnosed, provided there are no contraindications to this therapy.

12. In the first-line of immunosuppressive treatment, corticosteroids are used, most often prednisone/prednisolone orally at a dose of $1 \mathrm{mg} / \mathrm{kg} /$ day. Sometimes prednisone/prednisolone is used in combination with cyclophosphamide from the very beginning of treatment, however the latter one should not be administered in patients at childbearing age. In the second-line treatment for elimination of FVIII inhibitor in AHA rituximab is the most commonly prescribed drug; unfortunately, in this indication rituximab is not covered by the NFZ reimbursement. Posology of immunosuppressive drugs used in the treatment of AHA patients is shown in Table 5.

13. Care for a woman with pregnancy-associated or postpartum AHA should be taken by a team consisting of a gynecologist-obstetrician and a hematologist experienced in the treatment of patients with bleeding disorders.

14. The principles of treatment of a woman with pregnancy-associated and postpartum AHA do not differ from the principles of treatment in other groups of patients with AHA. This applies to the use of both hemostatic and immunosuppressive drugs. The only exception is the avoidance of cyclophosphamide and other alkylating drugs in women at childbearing age.

15. The AHA may recur, therefore, after successful FVIII inhibitor elimination, aPTT and plasma FVIII activity should 
be checked every month for the first 6 months, every 2-3 months for the next six months, and then every 6 months in the second year of follow-up.

16. Anticoagulants are contraindicated in a patient with AHA. After eliminating FVIII inhibitor and achieving AHA remission, in case of thromboembolism anticoagulants should be used according to generally accepted principles of therapy.

17. In case a woman with a history of pregnancy-associated and postpartum AHA is planning another pregnancy, she should be covered by specialist care of gynecologist and hematologist, to ensure monitoring of hemostasis system for prompt detection of the FVIII inhibitor recurrence. Management of the AHA relapse is the same as in the first AHA episode.

\section{Conflict of interests}

JW - conducted clinical trials and received honoraria for lecturing from Baxalta, Baxter, Bayer, CSL Behring, Biogen Idec, Novo Nordisk, Octapharma, Pfizer, Roche, Sanofi, Shire, SOBI, Werfen. $\mathrm{BB}$ - conducted clinical trials and received honoraria for lecturing from Baxalta, Baxter, Biogen Idec, Bioksel, Biomedica, CSL Behring, Grifols, Kselmed, Novo Nordisk, Octapharma, Roche, Shire, Siemens, Werfen.

EO - conducted clinical trials and received honoraria for lecturing from Baxalta, Baxter, Bayer, Sobi, Bioksel, Biomedica, CSL Behring, Grifols, Kselmed, Novo Nordisk, Octapharma, Roche, Shire, Siemens, Werfen.

$A B$ - conducted clinical trials and received honoraria for lecturing from Baxalta, Baxter, Bayer, Novo Nordisk, Octapharma, Shire $K D, P L, B P, P S:$ no conflicts of interest in this work.

Appendix 1. The list of Regional Blood Donation and Transfusion Centers (Regionalne Centrum Krwiodawstwa i Krwiolecznictwa, RCKiK)

\begin{tabular}{|c|c|c|}
\hline Name & Address & Contact \\
\hline Regional Blood Donation and Transfusion Center in Białystok & Marii Skłodowskiej-Curie 23, 15-950 Białystok & tel. 857447002 \\
\hline Regional Blood Donation and Transfusion Center in Bydgoszcz & Ks. Markwarta 8, 85-015 Bydgoszcz & tel. 523221871 \\
\hline Regional Blood Donation and Transfusion Center in Gdańsk & J. Hoene-Wrońskiego 4, 80-210 Gdańsk & tel. 585204020 \\
\hline Regional Blood Donation and Transfusion Center in Słupsk & Szarych Szeregów 21, 76-200 Słupsk & tel. 598422021 \\
\hline Regional Blood Donation and Transfusion Center in w Katowice & Raciborska 15, 40-074 Katowice & tel. 322087300 \\
\hline Regional Blood Donation and Transfusion Center in Racibórz & Sienkiewicza 3 A, 47-400 Racibórz & tel. 324181592 \\
\hline Regional Blood Donation and Transfusion Center in Kielce & Jagiellońska 66, 25-734 Kielce & tel. 413359400 \\
\hline Regional Blood Donation and Transfusion Center in Kraków & Rzeźnicza 11, 31-540 Kraków & tel. 122618820 \\
\hline Regional Blood Donation and Transfusion Center in Lublin & Żołnierzy Niepodległej 8, 20-078 Lublin & tel. 815326275 \\
\hline Regional Blood Donation and Transfusion Center in Łódź & Franciszkańska 17/25, 91-433 Łódź & tel. 426161400 \\
\hline Regional Blood Donation and Transfusion Center in Olsztyn & Malborska 2, 10-255 Olsztyn & tel. 895260156 \\
\hline Regional Blood Donation and Transfusion Center in Opole & Kośnego 55, 45-372 Opole & tel. 774410600 \\
\hline Regional Blood Donation and Transfusion Center in Poznań & Marcelińska 44, 60-354 Poznań & tel. 618863300 \\
\hline Regional Blood Donation and Transfusion Center in Kalisz & Kaszubska 9, 62-800 Kalisz & tel. 627676663 \\
\hline Regional Blood Donation and Transfusion Center in Rzeszów & Wierzbowa 14, 35-310 Rzeszów & tel. 178672030 \\
\hline Regional Blood Donation and Transfusion Center in Szczecin & Al. Wojska Polskiego 80/82, 70-482 Szczecin & tel. 914243600 \\
\hline Regional Blood Donation and Transfusion Center in Warszawa & Saska 63/75, 03-948 Warszawa & tel. 225146000 \\
\hline $\begin{array}{l}\text { Blood Donation and Transfusion Center of the Ministry of Internal } \\
\text { Affairs and Administration }\end{array}$ & Wołoska 137, 02-507 Warszawa & tel. 225081312 \\
\hline Military Blood Donation and Transfusion Center & Koszykowa 78, 00-671 Warszawa & tel. 261845066 \\
\hline Regional Blood Donation and Transfusion Center in Radom & Limanowskiego 42, 26-600 Radom & tel. 483400520 \\
\hline Regional Blood Donation and Transfusion Center in Wrocław & Czerwonego Krzyża 5-9, 50-345 Wrocław & tel. 713715810 \\
\hline Regional Blood Donation and Transfusion Center in Wałbrzych & Chrobrego 31, 58-303 Wałbrzych & tel. 746646310 \\
\hline Regional Blood Donation and Transfusion Center in Zielona Góra & Zyty 21, 65-046 Zielona Góra & tel. 683298360 \\
\hline
\end{tabular}

\section{REFERENCES}

1. Knoebl P, Marco P, Baudo F, et al. EACH2 Registry Contributors. Demographic and clinical data in acquired hemophilia A: results from the European Acquired Haemophilia Registry (EACH2). JThromb Haemost. 2012; 10(4):622631, doi: 10.1111/j.1538-7836.2012.04654.x, indexed in Pubmed: 22321904.

2. W Collins P, Chalmers E, Hart D, et al. United Kingdom Haemophilia Centre Doctors' Organization. Diagnosis and management of acquired coagulation inhibitors: a guideline from UKHCDO. Br J Haematol. 2013; 162(6): 758-773, doi: 10.1111/bjh.12463, indexed in Pubmed: 23889317.

3. Collins PW, Percy CL. Advances in the understanding of acquired haemophilia A: implications for clinical practice. Br J Haematol. 2010; 148(2): 183-194, doi: 10.1111/j.1365-2141.2009.07915.x, indexed in Pubmed: 19814739. 
4. Scandella D, Mattingly M, de Graaf S, et al. Localization of epitopes for human factor VIII inhibitor antibodies by immunoblotting and antibody neutralization. Blood. 1989; 74(5): 1618-1626, indexed in Pubmed: 2477082.

5. Buczma A, Windyga J. Nabyta hemofilia. Pol. Arch. Med. Wew. 2007: 5-6, 241-245.

6. Collins P, Macartney N, Davies R, et al. A population based, unselected, consecutive cohort of patients with acquired haemophilia $\mathrm{A}$. Br J Haematol. 2004; 124(1): 86-90, indexed in Pubmed: 14675412.

7. Collins PW, Hirsch S, Baglin TP, et al. UK Haemophilia Centre Doctors' Organisation. Acquired hemophilia A in the United Kingdom: a 2-year national surveillance study by the United Kingdom Haemophilia Centre Doctors' Organisation. Blood. 2007; 109(5): 1870-1877, doi: 10.1182/blood-2006-06-029850, indexed in Pubmed: 17047148.

8. Green D, Lechner K. A survey of 215 non-hemophilic patients with inhibitors to Factor VIII. Thromb Haemost. 1981; 45(3): 200-203, indexed in Pubmed: 6792737.

9. Kessler C, Nemes L. Acquired inhibitors to factor VIII. In: Rodriguez-Merchan EC, Lee CA. ed. Inhibitors in patients with hemophilia. Blackwell Science, Oxford 2002: 98-114.

10. Windyga J. Acquired hemophilia. J Transf Med. 2010; 4: 131-132.

11. Acquired factor VIII inhibitors in pregnancy: data from the Italian Haemophilia Register relevant to clinical practice. BJOG: An International Journal of Obstetrics and Gynaecology. 2003; 110(3): 311-314, doi: 10.1016/s1470-0328(03)01935-9.

12. Tengborn $L$, Baudo $F$, Huth-Kühne $A$, et al. EACH2 registry contributors. Pregnancy-associated acquired haemophilia A: results from the European Acquired Haemophilia (EACH2) registry. BJOG. 2012; 119(12): 1529-1537, doi: 10.1111/j.1471-0528.2012.03469.x, indexed in Pubmed: 22901076

13. Hauser I, Schneider B, Lechner K. Post-partum factor VIII inhibitors. A review of the literature with special reference to the value of steroid and immunosuppressive treatment. Thromb Haemost. 1995; 73(1): 1-5, indexed in Pubmed: 7740477

14. Michiels JJ. Acquired hemophilia A in women postpartum: clinical manifestations, diagnosis, and treatment. Clin Appl Thromb Hemost. 2000; 6(2): 82-86, indexed in Pubmed: 10775027.

15. Lulla RR, Allen GA, Zakarija A, et al.Transplacental transfer of postpartum inhibitors to factor VIII. Hemophilia. 2009; 15: 1166-1168.

16. Kasper CK, Pool JG. Letter: Measurement of mild factor VIII inhibitors in Bethesda units. Thromb Diath Haemorrh. 1975; 34(3): 875-876, indexed in Pubmed: 1209554.

17. Odnoczko E, Baran B, Windyga J. Z hemostazą na Ty. BioKsel, 2016.

18. Windyga J. Diagnostyka laboratoryjna zaburzeń hemostazy. In: Mariańska B, Fabijańska-Mitek J, Windyga J. ed. Badania laboratoryjne w hematologii. Podręcznik dla słuchaczy studiów medycznych. Wyd. Lek. PZWL, Warszawa 2003: 192-225.

19. Sallah S. Treatment of acquired haemophilia with factor eight inhibitor bypassing activity. Haemophilia. 2004; 10(2): 169-173, indexed in Pubmed: 14962206.

20. Ehrlich HJ, Henzl MJ, Gomperts ED. Safety of factor VIII inhibitor bypass activity (FEIBA): 10-year compilation of thrombotic adverse events. Haemophilia. 2002; 8(2): 83-90, indexed in Pubmed: 11952842.

21. Depka MV. NovoSeven: mode of action and use in acquired haemophilia. Intensive Care Medicine. 2002; 28(0): s222-s227, doi: 10.1007/s00134002-1469-1.

22. Baudo $F$, et al. Management of bleeding in acquired hemophilia A: results from the European Acquired Hemophilia (EACH2) Registry. Blood. 2012; 120: 39-46.

23. Zanon E, Pasca S, Santoro C, et al. Activated prothrombin complex concentrate (FEIBA) in acquired haemophilia A: a large multicentre Italian study - the FAIR Registry. Br J Haematol. 2019; 184(5): 853-855, doi: 10.1111/bjh.15175, indexed in Pubmed: 29528100.

24. Borg JY, Négrier C, Durieu l, et al. FEIBHAC Study Group. FEIBA in the treatment of acquired haemophilia $A$ : results from the prospective multicentre French ,FEIBA dans I'hémophilie A acquise' (FEIBHAC) registry. Haemophilia. 2015; 21(3): 330-337, doi: 10.1111/hae.12574, indexed in Pubmed: 25359571.

25. Windyga J, Chojnowski K, Klukowska A, et al. Część II: Wytyczne postępowania w hemofilii A i B powikłanej inhibitorem czynnika VIII i IX (2 wydanie). Acta Haematologica Polonica. 2017; 48(3): 137-159, doi: 10.1016/j.achaem.2017.08.001.

26. Gringeri A, Fischer K, Karafoulidou A, et al. European Haemophilia Treatment Standardisation Board (EHTSB). Sequential combined bypassing therapy is safe and effective in the treatment of unresponsive bleeding in adults and children with haemophilia and inhibitors. Haemophilia. 2011; 17(4): 630635, doi: 10.1111/j.1365-2516.2010.02467.x, indexed in Pubmed: 21323801.
27. Kruse-Jarres R, Kempton CL, Baudo F, et al. Acquired hemophilia A: Updated review of evidence and treatment guidance. Am J Hematol. 2017; 92(7): 695-705, doi: 10.1002/ajh.24777, indexed in Pubmed: 28470674.

28. Tarantino MD, Cuker A, Hardesty B, et al. Recombinant porcine sequence factor VIII (rpFVIII) for acquired haemophilia A: practical clinical experience of its use in seven patients. Haemophilia. 2017; 23(1): 25-32, doi: 10.1111/hae.13040, indexed in Pubmed: 27511890.

29. Huth-Kühne A, Baudo F, Collins $P$, et al. International recommendations on the diagnosis and treatment of patients with acquired hemophilia A. Haematologica. 2009; 94(4): 566-575, doi: 10.3324/haematol.2008.001743, indexed in Pubmed: 19336751.

30. Windyga J, Chojnowski K, Klukowska A, et al. W imieniu Grupy Roboczej ds. Hemostazy Polskiego Towarzystwa Hematologów i Transfuzjologów. Polskie zalecenia postępowania w nabytej hemofilii A. Medycyna Praktyczna. 2011; 10: 1-8.

31. Windyga J, et al. Activated prothrombin complex concentrate in combination with tranexamic acid: a single center experience for the treatment of mucosal bleeding and dental extraction in hemophilia patients with inhibitors. Hemophilia. 2016; 22: e465-e468.

32. Valentino LA, Holme PA. Should anti-inhibitor coagulant complex and tranexamic acid be used concomitantly? Haemophilia. 2015; 21(6): 709-714, doi: 10.1111/hae.12723, indexed in Pubmed: 26036756.

33. Narodowy Program Leczenia Chorych na Hemofilię i Pokrewne Skazy Krwotoczne. https://www.gov.pl/documents.

34. Collins PW, et al. Immunosuppression for acquired hemophilia A: results from the European Acquired Hemophilia Registry (EACH2). Blood. 2012; 120: 47-55.

35. Green D, Rademaker AW, Briët E. A prospective, randomized trial of prednisone and cyclophosphamide in the treatment of patients with factor VIII autoantibodies. Thromb Haemost. 1993; 70(5): 753-757, indexed in Pubmed: 8128430.

36. Kessler CM, Acs P, Mariani G. Acquired disorders of coagulation: the immune coagulopthies. In: Colman RW, Marder VJ, Clowes AW, George JN, Goldhaber SZ. ed. Hemostasis and thrombosis. Basic principles and clinical practice. Fifth edition. Lippincott Williams \& Wilkins, Philadelphia 2006: 1061-1084.

37. GREEN D. The management of acquired haemophilia. Haemophilia. 2006; 12(s5): 32-36, doi: 10.1111/j.1365-2516.2006.01383.x.

38. Delgado J, Jimenez-Yuste V, Hernandez-Navarro F, et al. Acquired haemophilia: review and meta-analysis focused on therapy and prognostic factors. Br J Haematol. 2003; 121(1): 21-35, indexed in Pubmed: 12670328.

39. Aggarwal A, Grewal R, Green RJ, et al. Rituximab for autoimmune haemophilia: a proposed treatment algorithm. Haemophilia. 2005; 11(1): 13-19, doi: 10.1111/j.1365-2516.2005.01060.x, indexed in Pubmed: 15660983.

40. D'Arena G, et al. The anti-CD20 monoclonal antibody rituximab to treat acquired hemophilia A. Blood Transfus. 2016; 14: 255-261.

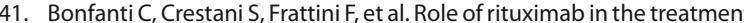
of postpartum acquired haemophilia A: a systematic review of the literature. Blood Transfus. 2015; 13(3): 396-400, doi: 10.2450/2014.0242-14, indexed in Pubmed: 25545867.

42. Sborov DW, Rodgers GM. How I manage patients with acquired haemophilia A. Br J Haematol. 2013; 161(2): 157-165, doi: 10.1111/bjh.12228, indexed in Pubmed: 23373521.

43. Schulman S, Langevitz P, Livneh A, et al. Cyclosporine therapy for acquired factor VIII inhibitor in a patient with systemic lupus erythematosus. Thromb Haemost. 1996; 76(3): 344-346, indexed in Pubmed: 8883268.

44. Lian ECY, Villar MJo, Noy LI, et al. Acquired factor VIII inhibitor treated with cyclophosphamide, vincristine, and prednisone. Am J Hematol. 2002; 69(4): 294-295, indexed in Pubmed: 11921026.

45. Obaji S, Rayment R, Collins P. Mycophenolate mofetil as adjunctive therapy in acquired haemophilia A. Haemophilia. 2018; 25(1): e59-e65, doi: 10.1111/hae.13658.

46. McFadyen JD, Tran H, Kaplan ZS. Factor VIII inhibitor eradication with bortezomib in acquired haemophilia A. Br J Haematol. 2017; 178(6): 986-987, doi: 10.1111/bjh.14185, indexed in Pubmed: 27431860.

47. Nemes L, Pitlik E. Ten years experience with immune tolerance induction therapy in acquired hemophilia. Hematologica. 2003; 88(suppl. 12): 64-68.

48. Zanon E, Pasca S, Siragusa S, et al. FAIR Study Group. Low dose of aPCC after the initial treatment in acquired haemophilia $A$ is useful to reduce bleeding relapses: Data from the FAIR registry. Thromb Res. 2019; 174: 24-26, doi: 10.1016/j.thromres.2018.12.006, indexed in Pubmed: 30551040. 
49. Baudo F, de Cataldo F. Italian Association of Haemophilia Centres (AICE): Register of acquired factor VIII inhibitors (RIIA). Acquired factor VIII inhibitors in pregnancy: data from the Italian Haemophilia Register relevant to clinical practice. BJOG. 2003; 110(3): 311-314, indexed in Pubmed: 12628274.
50. Coller BS, Hultin MB, Hoyer LW, et al. Normal pregnancy in a patient with a prior postpartum factor VIII inhibitor: with observations on pathogenesis and prognosis. Blood. 1981; 58(3):619-624, indexed in Pubmed: 6789845.

51. Solymoss S. Postpartum acquired factor VIII inhibitors: results of a survey. Am J Hematol. 1998; 59(1): 1-4, indexed in Pubmed: 9723568. 